\title{
Membrane Organization and Dynamics in Cell Polarity
}

\author{
Kelly Orlando and Wei Guo \\ Department of Biology, University of Pennsylvania, Philadelphia, Pennsylvania 19104-6018 \\ Correspondence: guowei@sas.upenn.edu
}

\begin{abstract}
The establishment and maintenance of cell polarity is important to a wide range of biological processes ranging from chemotaxis to embryogenesis. An essential feature of cell polarity is the asymmetric organization of proteins and lipids in the plasma membrane. In this article, we discuss how polarity regulators such as small GTP-binding proteins and phospholipids spatially and kinetically control vesicular trafficking and membrane organization. Conversely, we discuss how membrane trafficking contributes to cell polarization through delivery of polarity determinants and regulators to the plasma membrane.
\end{abstract}

Cenk ell polarity is essential in most if not all eukaryotes for their development and physiological functions at the tissue and organism level. Although there are significant differences in gross morphology and function among various tissues and organisms, at the cellular level, the establishment and maintenance of cell polarity tend to follow common themes.

A basic feature of cell polarity is the asymmetric organization of the plasma membrane (see McCaffrey and Macara 2009; Nelson 2009). This is mostly achieved through membrane trafficking along cytoskeleton tracks under the control of signaling molecules. In general, membrane trafficking occurs through sequential budding, transport, and fusion of vesicles from donor membranes to acceptor membranes (for recent reviews, see Bonifacino and Glick 2004; Cai et al. 2007). During budding, protein complexes interact with phospholipids to induce membrane curvature and generate vesicular carriers that capture different cargos from the donor compartments. After vesicles form, they are delivered to their acceptor compartments, most often along the cytoskeletons. Vesicle fusion at the acceptor membrane is mediated by the assembly of SNARE (soluble $N$-ethylmaleimide-sensitive fusion protein attachment protein receptors) complexes. Before membrane fusion, proteins or protein complexes tether the vesicles to the acceptor membranes and likely promote SNARE assembly. The Arf and Rab family of small GTPases are localized to different membrane compartments and regulate various stages of membrane trafficking.

Polarized distribution of proteins at the plasma membrane often results from a balance of vesicle delivery and fusion with the plasma membrane ("exocytosis"), two-dimensional spread through the plasma membrane ("diffusion"), and internalization and membrane

Editors: Rong Li and Bruce Bowerman

Additional Perspectives on Symmetry Breaking in Biology available at www.cshperspectives.org

Copyright (C) 2009 Cold Spring Harbor Laboratory Press; all rights reserved; doi: 10.1101/cshperspect.a001321

Cite this article as Cold Spring Harb Perspect Biol 2009;1:a001321 
recycling ("endocytosis"). There are two main layers of regulation that control polarized protein transport and incorporation to the plasma membrane. The first involves sorting at the trans-Golgi network (TGN) and endosomal compartments, such as the recycling endosomes. Protein sorting involves recognition of sorting signals in the cargo proteins by the adaptor protein (AP) complexes. There are a number of different AP complexes, and each is localized to different membrane compartments and captures distinct sets of cargo proteins before targeting to their correct destination. Protein sorting before delivery to different domains of the plasma membrane has been best characterized in epithelial cells, which have distinctive basolateral and apical domains separated by junctional complexes. This layer of regulation has been discussed in a recent review (Mellman and Nelson 2008) and is further discussed by Nelson (Nelson 2009), so it will not be discussed further here.
The second layer of regulation of membrane protein polarization is through the polarized tethering and docking of vesicles at specific domains of the plasma membrane (Fig. 1). Tethering proteins (i.e., the exocyst) target secretory vesicles to specific domains of the plasma membrane and SNARE assembly eventually drives membrane fusion. Proteins at the plasma membrane can be retrieved back into the cell via endocytosis. These proteins are internalized via clathrin-coated pits, and transported through different endosomal compartments either for degradation in the lysosomes or for recycling back to the plasma membrane. The endosomal compartment that mediates the transport of internalized plasma membrane proteins back to the cell surface is called the "recycling endosome." Recycling endosomes are major sources of cargo destined to the plasma membrane for exocytosis in many types of cells.

Signaling molecules such as the Rho family of small GTPases spatially and kinetically

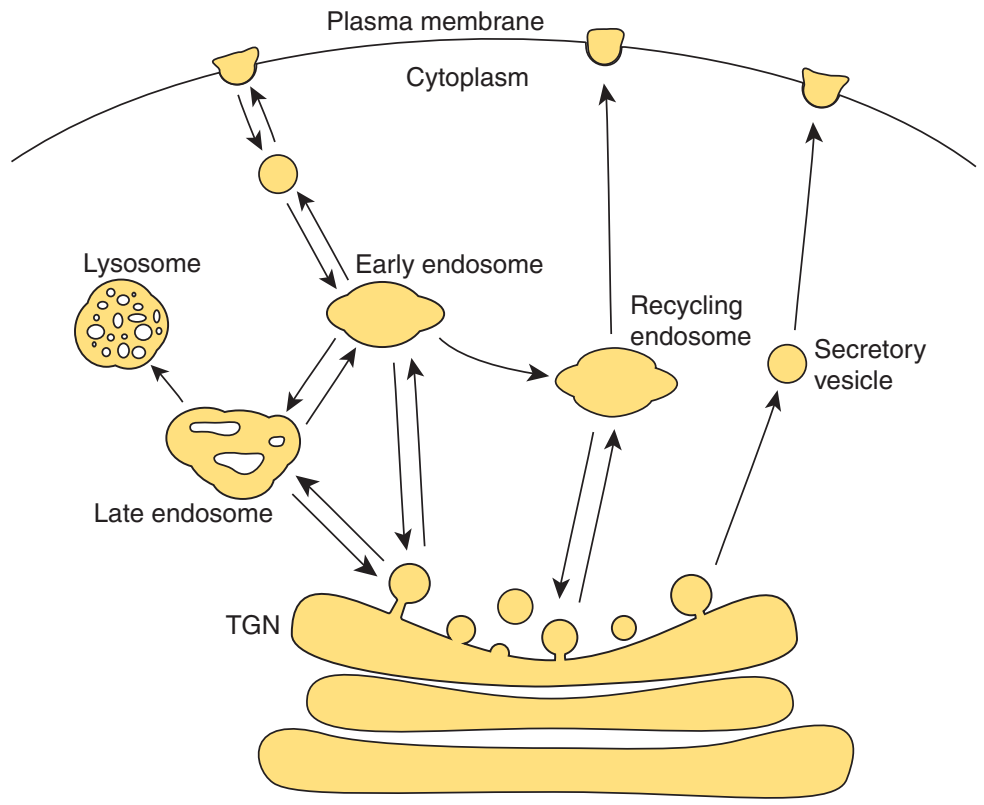

Figure 1. Membrane trafficking to the plasma membrane. Schematic of the endocytic and exocytic routes involving trans-Golgi network (TGN), endosomal compartments, and the plasma membrane. During exocytosis, cargo leaves the TGN or recycling endosomes in vesicular carriers to the plasma membrane. Once on the membrane, proteins can be internalized and transported to early endosomes, and then either travel through late endosomes to the lysosome to be degraded or return to the plasma membrane through the recycling endosomes. Early endosomes may serve as sorting stations for the next stages of cargo transport. 
regulate membrane trafficking during cell polarization (see McCaffrey and Macara 2009; Slaughter et al. 2009). Reversely, vesicular trafficking is required for the polarized deposition and accrual of these regulators. In the first part of this article, we examine the membrane organization and dynamics of cell polarity, focusing on the polarized tethering and docking of vesicles at the plasma membrane. We highlight key components and regulators of polarized exocytosis including the exocyst, small GTPases, and phospholipids. We also use different organisms and systems to show analogous mechanisms during cell polarization. In the second part of this article, we focus on the aforementioned reciprocal effects of cell polarity and membrane trafficking using two representative examples, one from yeast (Cdc42 polarization) and one in mammalian epithelial cells (E-cadherin trafficking).

\section{SPATIAL REGULATION OF MEMBRANE TRAFFIC}

Exocytosis-vesicle docking and fusion with the plasma membrane-is a fundamental membrane trafficking event in eukaryotes: It mediates the incorporation of proteins and lipids into the plasma membrane as well as the release of cargos to the extracellular environment. In most cells, exocytosis is polarized: Secretory vesicles generated from the TGN or endosomal compartments are targeted to specific regions of the plasma membrane by spatial cues and by traveling along cytoskeletal tracks. On reaching their destination, vesicles are tethered to the plasma membrane mediated by the exocyst complex, and eventually fuse to the plasma membrane through the involvement of SNARE proteins (Fig. 2).

\section{Tethering of Secretory Vesicles at the Plasma Membrane by the Exocyst}

The exocyst is an evolutionarily conserved octameric protein complex consisting of Sec3, Sec5, Sec6, Sec8, Sec10, Sec15, Exo70, and Exo84. Novick and Schekman identified genes encoding six members of the exocyst complex in the late 1970s using a genetic screen to isolate mutants involved in secretion in the budding yeast Saccharomyces cerevisiae (Novick et al. 1980). These proteins were later identified as part of a high molecular weight complex

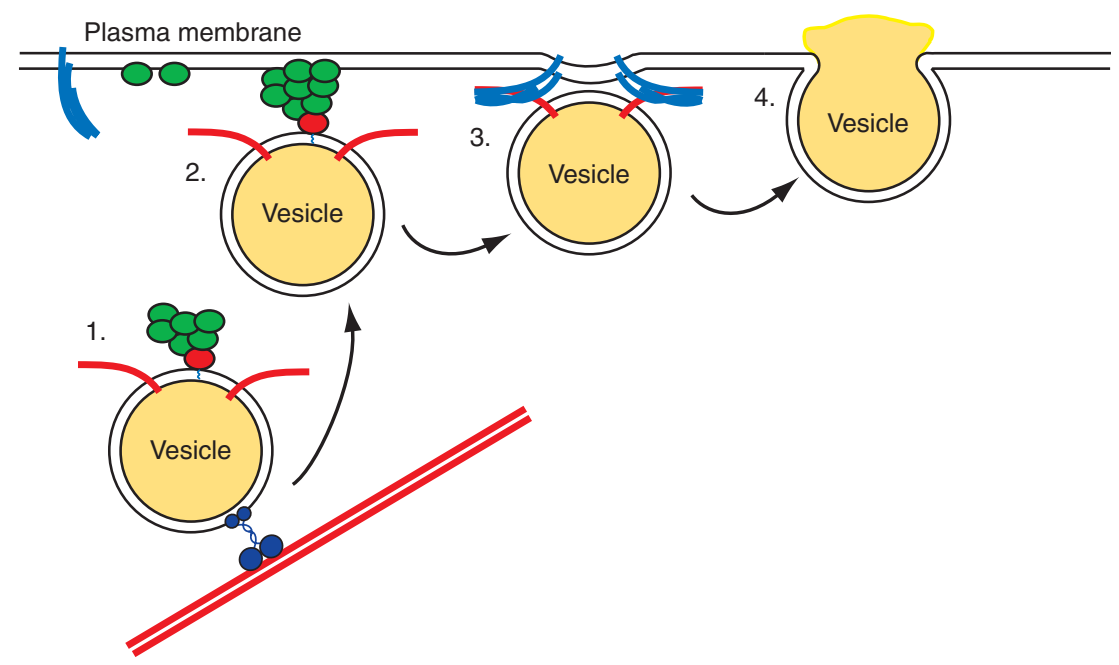

Figure 2. Late stages of exocytosis at the plasma membrane. 1. Secretory vesicles carrying the Rab protein (red), $\mathrm{v}$-SNAREs (red curves), and members of the exocyst complex (green) are delivered to the plasma membrane along the cytoskeleton (red lines) via motors (blue). 2. The vesicle is tethered to the plasma membrane by the exocyst complex. 3 and 4. The t-SNAREs (blue curves) on the plasma membrane bind to v-SNAREs on the vesicle, and the assembly of the SNARE complex drives membrane fusion. 
(Bowser and Novick 1991; Bowser et al. 1992; TerBush and Novick 1995; TerBush et al. 1996). The exocyst complex is conserved from yeast to mammals: All eight exocyst subunits share sequence homology across species (Ting et al. 1995; Hsu et al. 1996; Kee et al. 1997; Guo et al. 1997; Guo et al. 1999a; Matern et al. 2001). In yeast, exocyst mutants accumulate post-Golgi secretory vesicles in the cell (Novick et al. 1980; Guo et al. 1999a; Zhang et al. 2005a; He et al. 2007a). In Madin-Darby canine kidney (MDCK) cells, the exocyst has been shown to mediate exocytosis at the basolateral and apical domains (Grindstaff et al. 1998; Oztan et al. 2007). In adipocytes, the exocyst mediates exocytosis of the glucose transporter Glu4 in response to insulin stimulation (Inoue et al. 2003). Biochemical and genetic analyses in yeast suggest that the exocyst functions at a step after the delivery of secretory vesicles to the plasma membrane but before the assembly of the SNARE complex and vesicle fusion (Grote et al. 2000). Thus, the exocyst complex likely functions as a tether that mediates the initial contact between the secretory vesicles and the plasma membrane before docking and fusion (Pfeffer 1999; Hsu et al. 2004; He and Guo 2009).

The localization of the exocyst usually corresponds to sites of active exocytosis and cell surface expansion. During yeast budding, the exocyst is localized to the "bud tip," the site of daughter cell surface expansion (TerBush et al. 1995; Finger et al. 1998; Guo et al. 1999a). This polarized pattern of localization stands in contrast to that of t-SNAREs, which are distributed along the entire plasma membrane (Brennwald et al. 1994). In plants, exocyst subunits are localized at the apex of growing pollen tubes (Hála et al. 2008). In mammalian cells, although the exocyst mostly localizes to internal membrane compartments such as Golgi and recycling endosomes (Yeaman et al. 2001; Ang et al. 2003; Fölsch et al. 2003; Oztan et al. 2007), it is recruited to designated regions of the plasma membrane where active exocytosis and membrane expansion occur. For example, in neurons undergoing differentiation or synapse formation, the exocyst is enriched at the expanding neurites and discrete puncta along axons where synapses are forming (Hsu et al. 1996; Kee et al. 1997; Hazuka et al. 1999; Vega and Hsu, 2001; Brown et al. 2001; Murthy et al. 2003). In migrating cells, the exocyst is recruited to the plasma membrane at the leading edge (Zuo et al. 2006; Rosse et al. 2006). During the formation of epithelial cell monolayers, the exocyst is recruited to the plasma membrane at sites of cell-cell contact (Grindstaff et al. 1998), where it targets vesicles that carry proteins to the basolateral domain. The selective targeting of secretory vesicles to the basolateral domain beneath the cell-cell junction is important for the formation of epithelial monolayers (Grindstaff et al. 1998). The localization of the exocyst suggests that it is a target of signaling molecules that spatially regulate exocytosis at sites of membrane expansion.

It was proposed that two of the exocyst subunits, Exo70 and Sec3, function as landmarks at the plasma membrane for the remaining exocyst components, which arrive on postGolgi secretory vesicles along the actin cables (Boyd et al. 2004). The assembly of the exocyst complex may tether secretory vesicles to the plasma membrane. Recently, it was found that the yeast Exo70 (He et al. 2007b) and Sec3 (Zhang et al. 2008) bind directly to $\mathrm{PI}(4,5) \mathrm{P}_{2}$ on the plasma membrane. This proteinlipid interaction is conserved from yeast to mammals (Liu et al. 2007). These interactions play a critical role in recruiting Exo70, Sec3, and ultimately the other exocyst components to the plasma membrane for vesicle tethering (Fig. 3).

\section{Spatial and Kinetic Control of Membrane Trafficking by Small GTPases}

Exocytosis is tightly controlled in eukaryotic cells. Because vesicle tethering takes place before SNARE-mediated membrane fusion, spatial and temporal regulation of the exocyst is crucial to determining where and when exocytosis takes place. Consistent with this notion, the exocyst has been found to be under the control of a number of small 


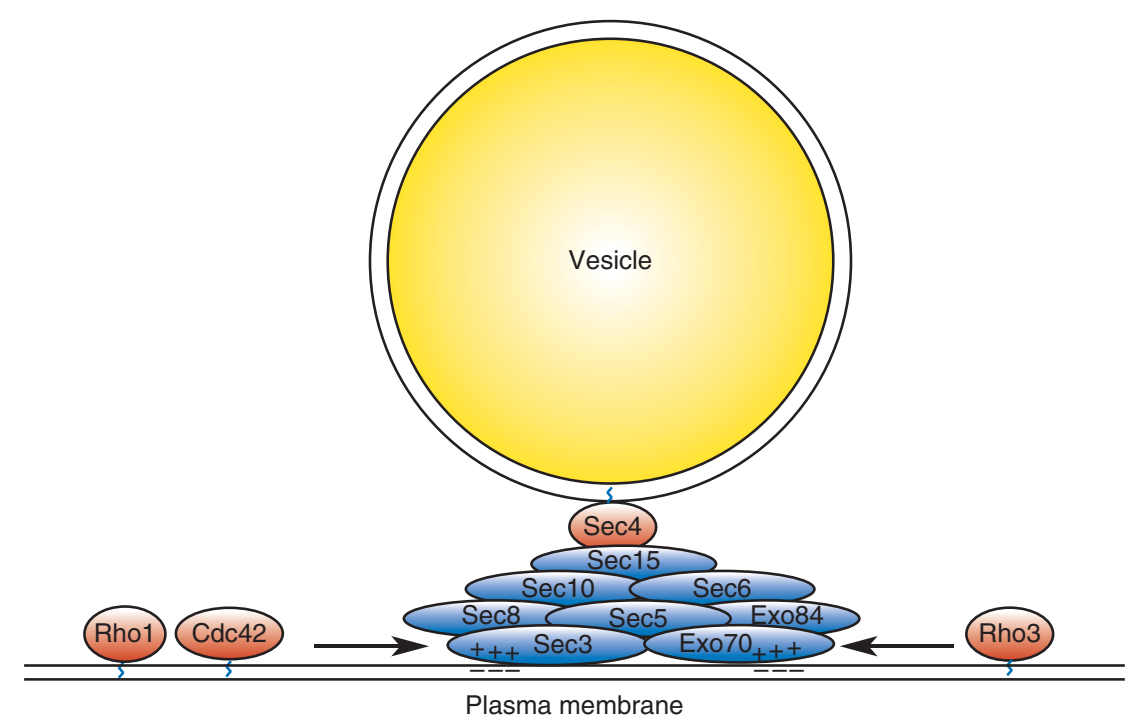

Figure 3. The exocyst complex. Schematic representation of the exocyst complex tethering a vesicle to the plasma membrane. The exocyst components (Sec3, Sec5, Sec6, Sec8, Sec10, Sec15, Exo70, and Exo84) are represented by blue rods. The GTPases are represented by red circles. Sec3 and Exo70 associate directly with the plasma membrane through their basic residues that bind to $\mathrm{PI}(4,5) \mathrm{P}_{2}$. The Rab GTPase Sec4 binds to secretory vesicles, and interacts with the exocyst component Sec15. This interaction promotes the assembly of the exocyst complex at the plasma membrane. Sec3 is known to interact with Rhol and Cdc42, whereas Exo70 interacts with Rho3. These small GTPases may regulate the polarization and activation of the exocyst at the plasma membrane.

GTPases in a variety of cells (for review, see Novick and Guo 2002; Lipschutz and Mostov 2002). In this article, we focus on the roles of the Rab and Rho proteins.

\section{The Rab Family of Small GTP-binding Proteins}

The Rab GTPases are master regulators of membrane trafficking. Members of the Rab family are localized to distinct membrane compartments and control vesicular trafficking through their interactions with specific tethering proteins and the cytoskeleton (Zerial and McBride 2001; Grosshans et al. 2006). Sec4 is a Rab protein that regulates exocytic traffic between the TGN and plasma membrane in yeast (Salminen and Novick 1987). The exocyst component Sec15 directly interacts with the GTP-bound form of Sec4 (Guo et al. 1999b). Through this interaction, Sec4 controls the assembly of the exocyst complex that is needed for the tethering of secretory vesicles at the plasma membrane. In other eukaryotes, Rab proteins such as Rab11 and Rab8, which are implicated in membrane trafficking to the plasma membrane, were also shown to interact with Sec15 (Zhang et al. 2004; Wu et al. 2005; Oztan et al. 2007). Together, these studies suggest that the exocyst functions as a downstream effector of Rab proteins to mediate vesicle tethering at the plasma membrane in eukaryotic cells. Another downstream effector of Sec4 is Sro7, the yeast homolog of lethal giant larvae (lgl), implicated in epithelial polarity (Grosshans et al. 2006; see Prehoda 2009). Sro7 was shown to bind to the t-SNARE protein Sec9 and is implicated in SNARE assembly (Lehman et al. 1999; Hattendorf et al. 2007). Sro7 also directly interacts with the exocyst component Exo84; disruption of the Sro7-Exo84 binding in cells lead to intracellular accumulation of secretory vesicles and defects in cell morphogenesis (Zhang et al. 2005b). 
One of the Sec4 homologs in mammalian cells is Rab8, which selectively regulates basolateral membrane transport in kidney epithelial cells (Ang et al. 2003). In fibroblasts, the guanine nucleotide exchange factor (GEF) for Rab8, Rabin8, was shown to regulate the remodeling of actin and formation of polarized cell surface domains (Hattula et al. 2002). Recently, Rab8 and Rabin8 were shown to be involved in primary cilium formation, most likely by regulating polarized delivery and docking of secretory vesicles carrying ciliary proteins at the base of the cilium (Yoshimura et al. 2007; Nachury et al. 2007).

Besides their role in regulating vesicle tethering, Rab GTPases also interact with the cytoskeleton. In yeast, the Rab11 homologs, Ypt31 and Ypt32, are thought to regulate vesicle budding from the TGN (Jedd et al. 1997). It was shown that the GTP-bound form of Ypt31/32 directly interacts with Myo2, a myosin $\mathrm{V}$ motor that mediates the polarized transport of secretory vesicles along actin cables; disruption of the interaction between Ypt31/32 and Myo2 blocks vesicle transport to daughter cells (Lipatova et al. 2008). Ypt31/32 may thus couple vesicle formation from the TGN with subsequent transport along actin cables to the bud tip. In mammals and Drosophila, Rab11 and its downstream effectors were shown to interact with myosin $\mathrm{V}$, and this interaction directs the transport of proteins from the recycling endosomes to the apical domain of the plasma membrane in epithelial cells (Hales et al. 2002; Cresawn et al. 2007; Li et al. 2007; Nelson 2009). This conserved myosin-membrane coordination was later shown to be important for the transport of a number of proteins such as cystic fibrosis transmembrane conductance regulator (CFTR) in airway cells and AMPA receptors into spines during synaptic plasticity (Swiatecka-Urban et al. 2007; Wang et al. 2008; Correia et al. 2008).

Ypt32 has also been shown to interact with Sec2, the guanine nucleotide exchange factor (GEF) for Sec4 (Ortiz et al. 2002). Similarly, in mammalian cells, Rab11 regulates the function of Rab8 through its GEF Rabin8 (Guo, unpublished results). This "Rab cascade" may coordinate vesicle formation at the donor compartment with downstream vesicle docking and fusion at the plasma membrane.

\section{The Rho Family of Small GTP-binding Proteins}

The function of the Rho family of small GTPases, especially Cdc42, in polarized membrane traffic has been shown in mammalian and yeast cells (see Slaughter et al. 2009; Nelson 2009). In kidney epithelial cells, Cdc42 was shown to be involved in the trafficking of proteins to the basolateral plasma membrane (Kroschewski et al. 1999; Musch et al. 2001; Cohen et al. 2001). Expression of Cdc42 mutants inhibits the exit of basolateral proteins from TGN (Müsch et al. 2001) and their recycling through the endosomes (Kroschewski et al. 1999). Cdc42 probably functions together with Rab8 (see previous discussion) in the same trafficking pathway in epithelial cells. In yeast, $\mathrm{Cdc} 42$ is a central regulator for the establishment of cell polarity, and it controls polarized exocytosis by two major mechanisms. First, it regulates the polarized organization of the actin cables, on which secretory vesicles are delivered to the bud tip. This is achieved through its downstream effectors, including Bnil, that regulate actin dynamics (for review, see Pruyne et al. 2004a; Park and Bi 2007). Second, Cdc42 regulates the localization and/ or activation of the exocyst complex (Zhang et al. 2001; Zhang et al. 2008). In several $c d c 42$ mutants, the exocyst loses its polarized localization (Zhang et al. 2001). Biochemical analyses have revealed that the amino terminus of Sec3 directly interacts with Cdc42 in its GTP-bound state. Disruption of this interaction leads to secretion and polarity defects (Zhang et al. 2001; Zhang et al. 2008). In addition to Cdc42, the amino terminus of Sec3 also interacts with another small GTPase, Rho1 (Guo et al. 2001). Rho1 and Cdc42 compete with each other for their binding to Sec3 in vitro (Zhang et al. 2001). Because Rho1 functions during cytokinesis (Tolliday et al. 2002) and cell wall remodeling (Cabib et al. 1998) in yeast, Rho1 may regulate Sec3 at a different cell cycle stage or physiological condition as Cdc42. 
In addition to interacting with $\mathrm{Cdc} 42$, a polybasic region at the amino terminus of Sec3 also directly binds to $\mathrm{PI}(4,5) \mathrm{P}_{2}$ in the plasma membrane (Zhang et al. 2008). Interestingly, swapping the amino terminus of Sec3 with the amino terminus of Gic2, a known downstream effector of $\mathrm{Cdc} 42$ that contains the well-characterized CRIB (Cdc42/ $\mathrm{Rac}$ Interaction/Binding) domain and a polybasic region, completely replaces the fulllength Sec3 function in yeast cells (Zhang et al. 2008; Orlando et al. 2008). It is possible that the binding of $\mathrm{Cdc} 42$ and $\mathrm{PI}(4,5) \mathrm{P}_{2}$ to $\mathrm{Sec} 3$ helps recruit Sec3 to the bud tip. It is also possible that Cdc42 and phospholipids function together to optimally activate $\mathrm{Sec} 3$ for exocytosis during yeast budding. The synergy in which $\mathrm{PI}(4,5) \mathrm{P}_{2}$ acts together with GTP-binding proteins to activate downstream effectors has been observed in other biological situations such as N-WASP activation for actin polymerization (Rohatgi et al. 2000; Prehoda et al. 2000).

Another piece of evidence for the role of Cdc42 in exocytosis came from the analysis of a specific allele of $c d c 42$ mutant, $c d c 42-6$ (Adamo et al. 2001). In this mutant, postGolgi secretory vesicles accumulate in the cytoplasm at the restrictive temperature. It has been shown that yeast cells have at least two types of secretory vesicles that are delivered to the plasma membrane for exocytosis (Harsay and Bretscher 1995; Harsay and Schekman 2002). The invertase vesicles carry proteins such as invertase, acid phosphatase, and possibly the general amino acid permease (Roberg et al. 1997), which are secreted only under certain specific physiological conditions. The Bgl2 vesicles contain materials for plasma membrane expansion and cell wall remodeling such as the endoglucanase Bgl2. The $c d c 42-6$ mutant only accumulates Bgl2 vesicles in the cell. Interestingly, all of the mutant alleles of the exocyst component Exo70 were also primarily defective in the secretion of $\mathrm{Bgl} 2$ vesicles, but not in the secretion of invertase vesicles (He et al. 2007a). Furthermore, in both cdc42-6 and exo70 mutants, the vesicle accumulation phenotype was observed only in small-budded cells, suggesting that Cdc42 and Exo70 are critical for exocytosis during the early stages of asymmetric growth in yeast. Characterization of these mutants showed an intimate coupling between exocytosis and polarized cell growth. The phenotypic similarity of cdc42-6 and exo70 mutants also suggests that Exo70 and $\mathrm{Cdc} 42$ function in the same pathway, which is specifically activated to meet the demand for asymmetric cell growth in the daughter cell. Exo70 is likely under the control of Cdc42. How Cdc42 controls Exo70 function is unknown.

In addition to $\mathrm{Cdc} 42$, another Rho GTPase, Rho3, was reported to regulate exocytosis (Adamo et al. 1999). Furthermore, it was shown that Rho3 binds to Exo70 in its GTP-bound form (Robinson et al. 1999). However, Exo70 mutants that are deficient in Rho3 binding have no defect in exocytosis (He et al. 2007a; Hutagalung et al. 2009). The mechanism by which Rho3 regulates exocytosis remains unclear.

In mammalian cells, it was found that TC10, a homolog of Cdc42, interacts with Exo70, and this interaction was shown to be important for Glut4 incorporation to the plasma membrane in adipocytes in response to insulin signaling (Inoue et al. 2003). Later studies showed that TC10 activity is coupled to vesicle fusion at the plasma membrane (Cheng et al. 2005; Kawase et al. 2006). Together, a conserved function of Cdc42/TC10 family proteins in exocytosis seems to be emerging.

\section{Phosphoinositides Regulate Plasma Membrane Asymmetry}

In addition to small GTPase proteins, another set of membrane traffic regulators are the lipids phosphatidylinositol (PI) and its phosphorylated species (see McCaffrey and Macara 2009). Different phosphoinositides are associated with different membrane compartments in the eukaryotic cell: $\mathrm{PI}(4,5) \mathrm{P}_{2}$ and $\mathrm{PI}(3,4,5) \mathrm{P}_{3}$ are mostly found at the plasma membrane, $\mathrm{PI}(3) \mathrm{P}$ and $\mathrm{PI}(3,5) \mathrm{P}_{2}$ are associated with various types of endosomes, $\mathrm{PI}(4) \mathrm{P}$ is associated with the Golgi, and $\mathrm{PI}(3,5) \mathrm{P}_{2}$ and $\mathrm{PI}(5) \mathrm{P}$ are associated with multi-vesicular bodies (De Matteis and Godi 2004; Behnia 
and Munro 2005; Di Paolo and De Camilli 2006). The specific subcellular localization of each of these phospholipids not only contributes to defining the identities of these organelles, but also regulates trafficking at different membrane compartments by recruiting specific sets of effector proteins.

Here, we focus on the role of the plasma membrane phosphoinositides $\mathrm{PI}(4,5) \mathrm{P}_{2}$ and $\mathrm{PI}(3,4,5) \mathrm{P}_{3}$ as signaling molecules for cell polarity. The levels of $\mathrm{PI}(4,5) \mathrm{P}_{2}$ and $\mathrm{PI}(3,4,5) \mathrm{P}_{3}$ on the plasma membrane at a given site are regulated by PI4P 5-kinases, PI 3-kinase, and PTEN phosphatase, which add or remove, respectively, a phosphate from the inositol ring (Leevers et al. 1999). One model system that has contributed significantly to our understanding of the role of phospholipids in the establishment of cell polarity is Dictyostelium discoideum. In resting cells, PTEN is localized uniformly along the plasma membrane, whereas PI 3-kinase is localized to the cytosol; during exposure to a gradient of chemoattractants, PI 3-kinase becomes localized to the leading edge of migrating cells, whereas PTEN is excluded from the leading edge and translocates to the lateral and posterior areas of the plasma membrane (Funamoto et al. 2002; Iijima and Devreotes 2002; Huang et al. 2003; Willard and Devreotes 2006). High concentrations of $\mathrm{PI}(3,4,5) \mathrm{P}_{3}$ at the leading edge generated by PI 3-kinase recruit proteins with $\mathrm{PI}(3,4,5) \mathrm{P}_{3}$-binding domains such as Akt, resulting in actin polymerization, pseudopod formation, and ultimately chemotaxis (Fig. 4A,B). Cells lacking PTEN have defects in polarization and chemotaxis (Iijima and Devreotes 2002). In addition to Dictyostelium, PTEN, $\mathrm{PI}(4,5) \mathrm{P}_{2}$, and $\mathrm{PI}(3,4,5) \mathrm{P}_{3}$ have been found to play important roles in directional migration of other cell types. For example, $\mathrm{PI}(3,4,5) \mathrm{P}_{3}$ is localized to the leading edge of neutrophils and the growth cone of developing neurons (Servant et al. 2000; Li et al. 2003; Shi et al. 2003; Aoki et al. 2005). Deletion of PTEN in Caenorhabditis elegans or overexpression of PTEN in hippocampal neurons results in aberrant polarization (Jiang et al. 2005; Adler et al. 2006).
Similarly, epithelial membrane asymmetry involves phosphoinositides and Cdc42. In polarized Madin-Darby canine kidney (MDCK) cells, $\mathrm{PI}(3,4,5) \mathrm{P}_{3}$ is localized to the basolateral membrane (Gassama-Diagne et al. 2006; Martin-Belmonte et al. 2007). Studies using a three-dimensional cystogenesis model showed that PTEN localizes to the apical membrane during epithelial morphogenesis, where it excludes $\mathrm{PI}(3,4,5) \mathrm{P}_{3}$ from this domain (Martin-Belmonte et al. 2007) (Fig. 4B,D). It was further shown that $\mathrm{PI}(4,5) \mathrm{P}_{2}$ recruits the adaptor protein annexin2 to the apical domain, which in turn recruits $\mathrm{Cdc} 42$ and its downstream effector, the aPKC/Par6 complex. Pinal and colleagues showed that the aPKC/ Par3/Par6 complex recruits PTEN to the developing cell-cell junctions in Drosophila photoreceptor epithelial cells, and this finetuning of $\mathrm{PI}(3,4,5) \mathrm{P}_{3}$ level is important for apical morphogenesis (Pinal et al. 2006). It is interesting to note that $\mathrm{Cdc} 42$ activation of the aPKC/Par3/Par6 complex has also been shown to play an essential role in cell polarization during migration (for review, see Etienne-Manneville et al. 2005).

Ectopic insertion of $\mathrm{PI}(3,4,5) \mathrm{P}_{3}$ to the apical domain of polarized MDCK cells was shown to induce protrusion of membranes enriched with basolateral markers, whereas exogenous $\mathrm{PI}(4,5) \mathrm{P}_{2}$ targets apical proteins to the basolateral domain (Gassama-Diagne et al. 2006; Martin-Belmonte et al. 2007). It is likely that vesicular trafficking events such as transcytosis redirect membrane protein incorporation to the apical or basolateral membranes in response to a shift in the local ratio of phosphoinositides. As mentioned earlier, in both yeast and mammalian cells, exocyst components Sec3 and Exo70 interact directly with $\mathrm{PI}(4,5) \mathrm{P}_{2}$, and this interaction is important for vesicle tethering at the plasma membrane during exocytosis (He et al. 2007b; Liu et al. 2007; Zhang et al. 2008). It is therefore likely that secretion machinery such as the exocyst complex is recruited to specific domains of the plasma membrane for exocytosis. Indeed, the exocyst has been shown to be involved in secretion at both the basolateral 
A

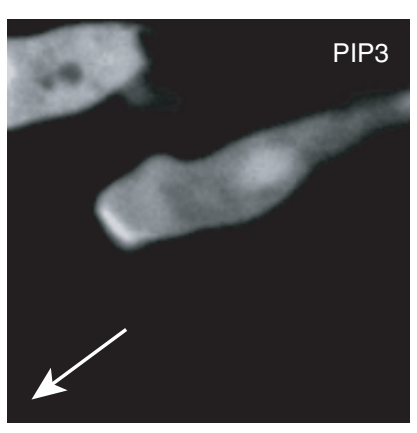

C

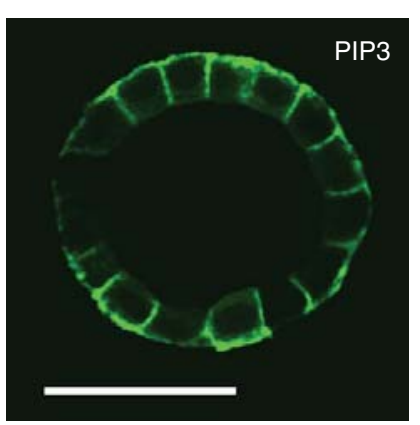

B

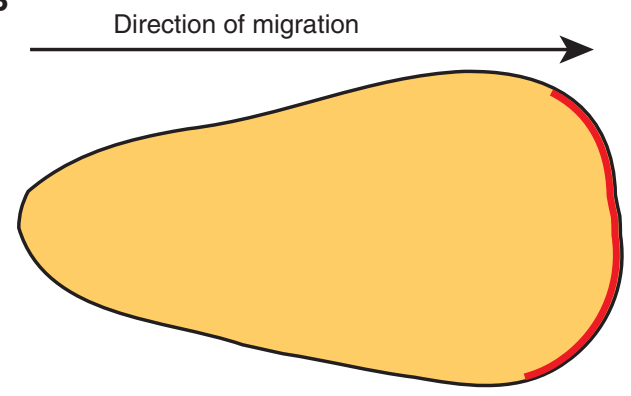

D

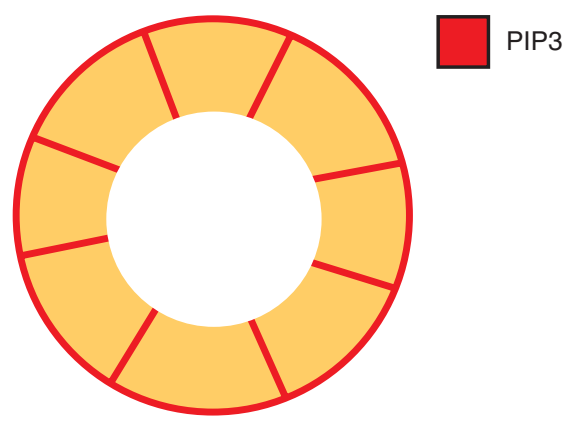

Figure 4. $\mathrm{PI}(3,4,5) \mathrm{P}_{3}$ localization in polarized cells. $(A) \mathrm{PI}(3,4,5) \mathrm{P}_{3}$ localization in migrating Dictyostelium. $\mathrm{PH}_{\mathrm{Crac}}-\mathrm{GFP}$ is a $\mathrm{PH}$-domain-containing protein that is a known probe for $\mathrm{PI}(3,4,5) \mathrm{P}_{3}$. $\mathrm{PH}_{\mathrm{Crac}}-\mathrm{GFP}$ is localized to the leading edge in migrating Dictyostelium cells (Funamoto et al. 2002). The arrow represents direction of migration toward a cAMP-filled pipet tip in the lower left corner. The average length of a migrating Dictyostelium is $20 \mu \mathrm{m}$ (Courtesy of P. Devreotes, Johns Hopkins University). (B) Schematic showing the localization of $\mathrm{PI}(3,4,5) \mathrm{P}_{3}$ in a migrating Dictyostelium cell. $(C) \mathrm{PI}(3,4,5) \mathrm{P}_{3}$ localization in polarized Madin-Darby canine kidney (MDCK) epithelial cyst. GFP-PH-Akt is also a probe for PI $(3,4,5) \mathrm{P}_{3}$, and is localized to the basal and lateral domains of MDCK cells in cysts (Martin-Belmonte et al. 2007). Scale bar represents $50 \mu \mathrm{m}$ (Courtesy of K. Mostov and W. Yu, UCSF). (D) Schematic showing the localization of $\mathrm{PI}(3,4,5) \mathrm{P}_{2}$ in an MDCK cell cyst.

and apical domains (Grindstaff et al. 1998; Blankenship et al. 2007; Oztan et al. 2007; Cresawn et al. 2007).

In summary, different membrane phospholipids are enriched to distinct membrane compartments by the action of specific phosphatidylinositol kinases and phosphatases. Although the details differ between species and cell type, phospholipid localization plays a pivotal role in the regulation of cell polarity.

\section{THE ROLE OF MEMBRANE TRAFFIC IN THE DEVELOPMENT OF CELL POLARITY}

Although membrane activity is spatially and kinetically controlled by polarity regulators, membrane traffic itself is a major contributing factor to cell polarization. Researchers in the field investigate the role of membrane traffic in cell polarity from two different angles. First, protein-sorting machinery at the trans-Golgi network and endosomal compartments together with their regulators such as $\mathrm{Cdc} 42$ direct the delivery of different proteins to distinct domains of the plasma membrane, thus contributing to the maintenance of cell surface asymmetry. Second, membrane trafficking is needed for the discrete distribution of key polarity regulators. The first aspect, involving protein sorting, has been discussed in two excellent reviews (Rodriguez-Boulan et al. 2005; Mellman and Nelson 2008; also see Nelson 2009). Here, we focus on the second aspect using two well-studied examples: polarization 
K. Orlando and W. Guo

of Cdc42 in budding yeast and junctional localization of E-cadherin in epithelia.

Polarization of Cdc42 by Membrane Traffic in Budding Yeast

Cdc42 is highly conserved across species and is a master regulator of cell polarity in many eukaryotes (Etienne-Manneville 2004; Park and Bi 2007). Thus, Cdc42 polarization provides an excellent example for discussing the role of membrane traffic in cell polarity. Cell polarity in budding yeast is established through the localization and activation of Cdc42 at a designated site defined by Bud1/ Rsr1, a small GTPase that functions in bud site selection (for recent review, see Park and Bi 2007; see Slaughter et al. 2009). However, polarized growth can be established in the absence of the intrinsic bud site selection program. Both an adaptor-based signaling system involving Bem1, Cdc24 (the GEF for Cdc42) and PAKs (the Cdc42 downstream effector) (Irazoqui et al. 2003; Kozubowski et al. 2008) (see Li and Bowerman 2009 for further discussion), and membrane trafficking are needed for robust asymmetric localization of $\mathrm{Cdc} 42$ in yeast cells. Wedlich-Soldner et al. found that constitutively active $\mathrm{Cdc} 42\left(\mathrm{Cdc} 42^{\mathrm{Q} 61 \mathrm{~L}}\right)$ formed a polar cap in yeast; the polar cap formation was independent of Bud1, but dependent on a functional exocytic pathway directed by the actin cytoskeleton (Wedlich-Soldner et al. 2003). Treatment of cells with the actin polymerization inhibitor latrunculin, mutations in the type $\mathrm{V}$ myosin Myo2 or tropomyosin, or mutations in the secretory pathway genes inhibited formation of the Cdc42 ${ }^{\mathrm{Q} 61 \mathrm{~L}}$ polar cap (Wedlich-Soldner et al. 2003). The actin-dependent Cdc42 polarization was also confirmed by studies using antibodies against endogenous $\mathrm{Cdc} 42$ (Irazoqui et al. 2005; Zajac et al. 2005; Kozminski et al. 2006). Mathematical simulation using the yeast system supports the hypothesis that local activation of Cdc42, subsequent actin polymerization through downstream Cdc42 effectors, and vesicular transport provide a positive feedback loop that leads to cell polarization (Wedlich-Soldner et al. 2003).
Further crosstalk between the polarity establishment complex and vesicular trafficking was characterized: Mutations in the Rab protein Sec4 or the exocyst component Sec5 not only lead to mislocalization of $\mathrm{Cdc} 42$, but also of Bem1, suggesting that exocytosis is necessary for the reinforcement of the adaptor-based signaling network (Zajac et al. 2005). Interestingly, the exocyst was found to interact with Bem1 in yeast lysates (Zajac et al. 2005). France and colleagues further showed that the carboxyl terminus of Sec15 directly binds to Bem1 (France et al. 2006). These data suggest that the exocyst and the polarity-establishment complex coordinate to control secretion and polarized growth.

Although exocytosis is important for the delivery of proteins to sites of cell polarization, endocytosis is also needed to counterbalance the continuous diffusion of these proteins along the plasma membrane. Polarization of membrane proteins results from a balance of exocytosis and endocytosis (Irazoqui et al. 2005; Marco et al, 2007). Endocytosis allows cargo to be internalized, in which it can then be recycled back to the site of polarization through the secretory pathway. It was shown that although depolymerization of all F-actin prevented polarization of most proteins at the bud tip, it did not prevent polarization of Cdc42 (Ayscough et al. 1997; Irazoqui et al. 2003). It was later shown that selective depolymerization of actin cables, but not actin patches, caused dispersal of $\mathrm{Cdc} 42$ from the bud tip (Irazoqui et al. 2005; Pruyne et al. 2004b). Actin patches are associated with sites of active endocytosis. Irazoqui et al. found that inhibition of endocytosis reduced dispersal of Cdc42 from the bud tip after loss of actin cables. This result suggests that a balance of exocytic and endocytic events controls Cdc42 polarization, and that continuous polarized transport of $\mathrm{Cdc} 42$ is necessary to counteract the effect of endocytosis.

In addition to endocytosis, small GTPases are recycled off the membrane and released into the cytoplasm through the action of a GDP disassociation inhibitor (GDI). In the fungus Cryptococcus neoformans, $\mathrm{Cdc} 42$ is 
mislocalized to the cytoplasm when the Rho GDI homolog is overexpressed (Price et al. 2008). This is consistent with published data that recombinant Rdil or overexpressed Rdil in yeast can extract Rho proteins from the plasma membrane or vacuole membrane (Eitzen et al. 2001; Tcheperegine et al. 2005; Tiedje et al. 2008). Therefore, recycling through GDIs may, like endocytosis, play an important role in the establishment and maintenance of polarity.

Overall, the constant cycle of endocytosis and exocytosis, together with GDI extraction, is important for maintaining cell polarity during yeast budding. This dynamic process may also be important in situations such as yeast mating projection formation, in which cells need to be flexible while responding to new polarity cues. Although we use Cdc42 as an example to illustrate the role of vesicular trafficking in cell polarity, other small GTPases have also been shown to exploit a similar mechanism. In hippocampal neurons, a positive feedback loop involves the small GTPase HRas and its downstream effector, PI 3-kinase. Ras activity at the site of axon formation activates PI 3-kinase, whereas increases of $\mathrm{PI}(3,4,5) \mathrm{P}_{3}$ level result in further recruitment and activation of HRas at the axon site through targeted vesicular transport (Fivaz et al. 2008).

\section{Membrane Trafficking of E-cadherin}

In multicellular organisms, cell-ECM and cellcell interactions are involved in establishing polarity. In general, epithelial cells grown in conditions lacking these interactions do not polarize but instead die by anoikis or develop into a tumor. E-cadherin, a member of the $\mathrm{Ca}^{2+}$-dependent adhesion receptor family, is one of the most important junction proteins for the establishment and maintenance of the apical-basolateral asymmetry in epithelial cells (Gumbiner 1996; Gumbiner et al. 1988; Larue et al. 1994; Uemura et al. 1996). E-cadherin engagement is necessary for localization of the exocyst. Members of the exocyst complex are recruited to the membrane during the initiation of cell polarity in MDCK cells and are associated with junctional complexes containing E-cadherin (Grindstaff et al. 1998; Yeaman et al. 2004). Nejsum and Nelson found that E-cadherin orients microtubules to direct vesicle trafficking from the Golgi to the basolateral membrane, and recruits a "targeting patch" including the exocyst to tether vesicles to the basolateral domain (Nejsum and Nelson 2007).

Although functioning as a regulator of polarized trafficking, E-cadherin itself is delivered via secretory vesicles as cargo to sites of polarity. Membrane trafficking pathways, including Golgi sorting, exocytosis, and later endosomal recycling, regulate polarized localization of E-cadherin to adherens junctions. E-cadherin contains sorting signals such as the dileucine motif that control its targeting to the basolateral domain in attached cells at the point of the Golgi complex and recycling endosomes (Miranda et al. 2001; Miranda et al. 2003). Proper localization of the exocyst in epithelial cells is necessary for the specific delivery of basolateral proteins characteristic of polarized cells, including E-cadherin (Grindstaff et al. 1998; Langevin et al. 2005); inhibition of exocyst function results in intracellular accumulation of E-cadherin (Langevin et al. 2005; Blankenship et al. 2007).

Adherens junctions must function to maintain the integrity of an epithelial monolayer, yet be flexible during tissue remodeling. Fluorescence recovery after photobleaching (FRAP) studies showed that proteins in epithelial junctions undergo dynamic remodeling even at steady state (Yamada et al. 2005; Shen et al. 2008). E-cadherin, an important member of the adherens junction, is dynamically regulated through endocytic recycling (for review, see Yap et al. 2007). Le et al. observed that the pool of E-cadherin undergoing endocytosis and recycling is increased in cells that either do not have or have lost cell-cell contacts, and that reformation of adherens junctions was inhibited when E-cadherin endocytosis was blocked (Le et al. 1999). Later studies found that recycling endosomes and the GTPase Rab11, a regulator 
of recycling endosome trafficking, control Ecadherin recycling and epithelial cell polarity (Classen et al. 2005; Desclozeaux et al. 2008). This continuous opposing traffic of E-cadherin between cytoplasmic pools and adherens junctions may allow the cell to better respond to changes in polarity cues. In conclusion, not only does E-cadherin regulate polarized exocytosis in epithelial cells, but also its own polarized localization is regulated by a number of different processes.

In addition to E-cadherin, other junctional proteins and polarity regulators also need dynamic membrane traffic for their localization and function. For examples, Rab13 was found to mediate endocytic recycling of occludin, thus regulating tight junction assembly (Terai et al. 2008). In Drosophila, mutations in endosomal proteins including Rab5 affect the localization of key polarity determinants such as Crumbs and cause polarity defects and eventually neoplastic tumors ( $\mathrm{Lu}$ and Bilder 2005); loss of the exocyst component Exo84 resulted in the mislocalization of Crumbs and affected apical identity (Blankenship et al. 2007).

The importance of membrane traffic in cell polarity has been shown not only in yeast budding and epithelial polarization, but also in a number of other physiological processes. For example, directional cell migration needs polarized membrane trafficking (Singer and Kupfer 1986; Bretscher 1996; Bretscher and Aguado-Velasco 1998). Inhibitors that disrupt membrane traffic inhibit cell motility (Bershadsky and Futerman 1994; Prigozhina and Waterman-Storer 2004). During cell migration, adhesion proteins such as integrins are rapidly endocytosed from the trailing edge of migrating cells, and subsequently exocytosed at the leading edge for substratum reattachment (for review, see Caswell and Norman 2006). The recycling of $\beta 1$ integrin through membrane trafficking is important for cell motility, and more importantly, for the directional persistence of migration (Roberts et al. 2001; Powelka et al. 2004; Proux-Gillardeaux et al. 2005; Tayeb et al. 2005; Li et al. 2005; Caswell and Norman 2006). Similarly, cells with disruption of the exocyst component
Exo70 also fail to maintain their direction during migration (Zuo et al. 2006). Recently, the role of Golgi in cell polarization was better appreciated. Disruption of Golgi structure and positioning in the cell not only affects polarized secretion, but also affects centrosome orientation and polarity during cell migration (Bisel et al. 2008; Yadav et al. 2009). Taken together, as was the case in yeast budding and epithelial polarization, membrane trafficking is important for the maintenance of polarity during cell migration.

\section{FUTURE PERSPECTIVES}

Studies using a variety of model systems over recent years have led to a better understanding of membrane organization and dynamics during cell polarization. These studies highlight the importance of the membrane traffic, cytoskeleton, and signaling proteins that spatially and kinetically regulate the generation and maintenance of asymmetric organization of the plasma membrane. Although we focus on the organization and dynamics of the plasma membrane in this article, other membrane aspects such as protein sorting and lipid composition also play essential roles in cell polarity.

There are still a number of important questions that remain unanswered in the field. Although we have now identified many key players that are involved in the organization of the membrane during cell polarization, how they interact with each other and the molecular mechanisms of their actions remain unclear. For example, at which stage does Cdc42 act on membrane traffic? How are membrane organization and cytoskeleton dynamics (illustrated in Mullins 2009) coordinated during cell polarization? Polarized membrane trafficking has been implicated in a number of biological processes, such as cell migration, cytokinesis, and ciliogenesis. How the secretion machinery is used and regulated during these processes are unclear. Many polarity regulators are implicated in diseases such as tumorigenesis. In fact, several proteins such as $l g l$ and Scribble were originally identified as tumor suppressors. It will be interesting to investigate how the loss 
of cell polarity is linked to tumorigenesis, and whether any of these polarity proteins could be potential drug targets for cancer treatment.

\section{ACKNOWLEDGMENTS}

Because of the broad nature of this subject, we were unable to provide a complete survey of the field of membrane dynamics in polarity, but instead chose to highlight a few key processes. We apologize for any reference we may have left out. We thank Drs. Wei Yu, Keith Mostov, and Peter P. Devreotes for sharing the unpublished cell images. We thank Erfei Bi, Bing He, Fei Wang, Charles Yeaman, Elias Spiliotis, Heike Fölsch, and Lauren Yokomizo for helpful discussions. Kelly Orlando is supported by a postdoctoral fellowship from the National Institute of Health. Research in Wei Guo's lab is supported by grants from the National Institutes of Health, American Heart Association, and the Pew Charity Fund.

\section{REFERENCES}

Adamo JE, Rossi G, Brennwald P. 1999. The Rho GTPase Rho3 has a direct role in exocytosis that is distinct from its role in actin polarity. Mol Biol Cell 10: 4121-4133.

Adamo JE, Moskow JJ, Gladfelter AS, Viterbo D, Lew DJ, Brennwald PJ. 2001. Yeast Cdc42 functions at a late step in exocytosis, specifically during polarized growth of the emerging bud. J Cell Biol 155: 581-592.

Adler CE, Fetter RD, Bargmann CI. 2006. UNC-6/Netrin induces neuronal asymmetry and defines the site of axon formation. Nat Neurosci 9: 511-518.

Ang AL, Fölsch H, Koivisto UM, Pypaert M, Mellman I. 2003. The Rab8 GTPase selectively regulates AP-1B-dependent basolateral transport in polarized Madin-Darby canine kidney cells. J Cell Biol. 163: 339-50.

Aoki K, Nakamura T, Fujikawa K, Matsuda M. 2005. Local phosphatidylinositol 3,4,5-trisphosphate accumulation recruits Vav2 and Vav3 to activate Rac1/Cdc42 and initiate neurite outgrowth in nerve growth factorstimulated PC12 cells. Mol Biol Cell 16: 2207-2217.

Ayscough KR, Stryker J, Pokala N, Sanders M, Crews P, Drubin DG. 1997. High rates of actin filament turnover in budding yeast and roles for actin in establishment and maintenance of cell polarity revealed using the actin inhibitor latrunculin-A. J Cell Biol 137: 399-416.

Behnia R, Munro S. 2005. Organelle identity and the signposts for membrane traffic. Nature 438: 597-604.

Bershadsky AD, Futerman AH. 1994. Disruption of the Golgi apparatus by brefeldin A blocks cell polarization and inhibits directed cell migration. Proc Natl Acad Sci 91: 5686-5689.

Bisel B, Wang Y, Wei JH, Xiang Y, Tang D, Miron-Mendoza M, Yoshimura S, Nakamura N, Seemann J. 2008. ERK regulates Golgi and centrosome orientation towards the leading edge through GRASP65. J Cell Biol 182: 837-843.

Blankenship JT, Fuller MT, Zallen JA. 2007. The Drosophila homolog of the Exo84 exocyst subunit promotes apical epithelial identity. J Cell Sci 120: 3099-3110.

Bonifacino JS, Glick BS. 2004. The mechanism of vesicle budding and fusion. Cell 116: 153-166.

Bowser R, Novick P. 1991. See15 Protein, an Essential Component of the Exocytotic Apparatus, Is Associated with the Plasma Membrane and with a Soluble 19.5S Particle. J Cell Biol 112: 1117-1131.

Bowser R, Muller H, Govindan B, Novick P. 1992. Sec8p and SeclSp are components of a plasma membraneassociated $19.5 \mathrm{~S}$ particle that may function downstream of Sec4p to control exocytosis. J Cell Biol 118: 1041-1056.

Boyd C, Hughes T, Pypaert M, Novick P. 2004. Vesicles carry most exocyst subunits to exocytic sites marked by the remaining two subunits, Sec3p and Exo70p. J Cell Biol 167: 889-901.

Brennwald P, Kearns B, Champion K, Keränen S, Bankaitis V, Novick P. 1994. Sec9 is a SNAP-25-like component of a yeast SNARE complex that may be the effector of Sec4 function in exocytosis. Cell 79: 245-258.

Bretscher MS. 1996. Getting membrane flow and the review cytoskeleton to cooperate in moving cells. Cell 87: 601-606.

Bretscher MS, Aguado-Velasco C. 1998. Membrane traffic during cell locomotion. Curr Opin Cell Biol 10: 537-541.

Brown DL, Heimann K, Lock J, Kjer-Nielsen L, van Vliet C, Stow JL, Gleeson PA. 2001. The GRIP domain is a specific targeting sequence for a population of trans-Golgi network derived tubulo-vesicular carriers. Traffic 2: 336-344.

Cabib E, Drgonova J, Drgon T. 1998. Role of small G proteins in yeast cell polarization and wall biosynthesis. Ann Rev Biochem 67: 307-333.

Cai H, Reinisch K, Ferro-Novick S. 2007. Coats, Tethers, Rabs, and SNAREs work together to mediate the intracellular destination of a transport vesicle. Dev Cell 12: 671-682.

Caswell PT, Norman JC. 2006. Integrin trafficking and the control of cell migration. Traffic 7: 14-21.

Cheng J, Wang H, Guggino WB. 2005. Regulation of cystic fibrosis transmembrane regulator trafficking and protein expression by a Rho family small GTPase TC10. J Biol Chem 280: 3731-3739.

Classen AK, Anderson KI, Marois E, Eaton S. 2005. Hexagonal packing of Drosophila wing epithelial cells by the planar cell polarity pathway. Dev Cell 9: 805-817.

Cohen D, Musch A, Rodriguez-Boulan E. 2001. Selective control of basolateral membrane protein polarity by Cdc42. Traffic 2: 556-564.

Correia SS, Bassani S, Brown TC, Lisé MF, Backos DS, El-Husseini A, Passafaro M, Esteban JA. 2008. Motor protein-dependent transport of AMPA receptors into 
K. Orlando and W. Guo

spines during long-term potentiation. Nat Neurosci 11: 457-466.

Cresawn KO, Potter BA, Oztan A, Guerriero CJ, Ihrke G Goldenring JR, Apodaca G, Weisz OA. 2007. Differential involvement of endocytic compartments in the biosynthetic traffic of apical proteins. $E M B O J \mathbf{2 6}$ : 3737-3748.

De Matteis MA, Godi A. 2004. PI-loting membrane traffic. Nat Cell Biol 6: 487-492.

Desclozeaux M, Venturato J, Wylie FG, Kay JG, Joseph SR, Le HT, Stow JL. 2008. Active Rab11 and functional recycling endosome are required for E-cadherin trafficking and lumen formation during epithelial morphogenesis. Am J Physiol Cell Physiol 295: C545-C556.

Di Paolo G, De Camilli P. 2006. Phosphoinositides in cell regulation and membrane dynamics. Nature 443: $651-657$.

Eitzen G, Thorngren N, Wickner W. 2001. Rholp and Cdc42p act after Ypt7p to regulate vacuole docking. EMBO J 20: 5650-5656.

Etienne-Manneville S. 2004. Cdc42-the centre of polarity. J Cell Sci 117: 1291-1300.

Etienne-Manneville S, Manneville JB, Nicholls S, Ferenczi MA, Hall A. 2005. Cdc42 and Par6-PKCzeta regulate the spatially localized association of Dlg1 and APC to control cell polarization. J Cell Biol 170: 895-901.

Finger FP, Hughes TE, Novick P. 1998. Sec3p is a spatial landmark for polarized secretion in budding yeast. Cell 92: 559-571.

Fivaz M, Bandara S, Inoue T, Meyer T. 2008. Robust neuronal symmetry breaking by Ras-triggered local positive feedback. Curr Biol 18: 44-50.

Fölsch H, Pypaert M, Maday S, Pelletier L, Mellman I. 2003. The AP-1A and AP-1B clathrin adaptor complexes define biochemically and functionally distinct membrane domains. J Cell Biol 163: 351-362.

France YE, Boyd C, Coleman J, Novick PJ. 2006. The polarity-establishment component Bemlp interacts with the exocyst complex through the Sec15p subunit. J Cell Sci 119: 876-888.

Funamoto S, Meili R, Lee S, Parry L, Firtel RA. 2002. Spatial and Temporal Regulation of 3-Phosphoinositides by PI 3-Kinase and PTEN Mediates Chemotaxis. Cell 109: 611-623.

Gassama-Diagne A, Yu W, ter Beest M, Martin-Belmonte F, Kierbel A, Engel J, Mostov K. 2006. Phosphatidylinositol3,4,5-trisphosphate regulates the formation of the basolateral plasma membrane in epithelial cells. Nat Cell Biol 8: 963-970.

Grindstaff KK, Yeaman C, Anandasabapathy N, Hsu SC, Rodriguez-Boulan E, Scheller RH, Nelson WJ. 1998. Sec6/8 complex is recruited to cell-cell contacts and specifies transport vesicle delivery to the basal-lateral membrane in epithelial cells. Cell 93: 731-740.

Grosshans BL, Ortiz D, Novick P. 2006. Rabs and their effectors: Achieving specificity in membrane traffic. PNAS 103: $11821-11827$.

Grote E, Carr CM, Novick PJ. 2000. Ordering the final events in yeast exocytosis. J Cell Biol 151: 439-452.

Gumbiner BM. 1996. Cell adhesion: The molecular basis of tissue architecture and morphogenesis. Cell 84: 345-357.
Gumbiner B, Stevenson B, Grimaldi A. 1988. The role of the cell adhesion molecule uvomorulin in the formation and maintenance of the epithelial junctional complex. J Cell Biol 107: 1575-1587.

Guo W, Grant A, Novick P. 1999a. Exo84p is an exocyst protein essential for secretion. J Biol Chem 274: 23558-23564.

Guo W, Tamanoi F, Novick P. 2001. Spatial regulation of the exocyst complex by Rhol GTPase. Nat Cell Biol 3: 353-360.

Guo W, Roth D, Gatti E, De Camilli P, Novick P. 1997. Identification and characterization of homologues of the Exocyst component Sec10p. FEBS Lett 404: 135-139.

Guo W, Roth D, Walch-Solimena C, Novick P. 1999b. The exocyst is an effecter for Sec4p, targeting secretory vesicles to sites of exocytosis. EMBO J 18: 1071-1080.

Hála M, Cole R, Synek L, Drdová E, Pecenková T, Nordheim A, Lamkemeyer T, Madlung J, Hochholdinger F, Fowler JE, et al. 2008. An exocyst complex functions in plant cell growth in Arabidopsis and tobacco. Plant Cell 20: $1330-1345$.

Hales CM, Vaerman JP, Goldenring JR. 2002. Rab11 family interacting protein 2 associates with Myosin $\mathrm{Vb}$ and regulates plasma membrane recycling. J Biol Chem 277: 50415-50421.

Harsay E, Bretscher A. 1995. Parallel secretory pathways to the cell surface in yeast. J Cell Biol 131: 297-310.

Harsay E, Schekman R. 2002. A subset of yeast vacuolar protein sorting mutants is blocked in one branch of the exocytic pathway. J Cell Biol 156: 271-285.

Hattendorf DA, Andreeva A, Gangar A, Brennwald PJ, Weis WI. 2007. Structure of the yeast polarity protein Sro7 reveals a SNARE regulatory mechanism. Nature 446: 567-571.

Hattula K, Furuhjelm J, Arffman A, Peranen J. 2002. A Rab8-specific GDP/GTP exchange factor is involved in actin remodelling and polarized membrane transport. Mol Biol Cell 13: 3268-3280.

Hazuka CD, Foletti DL, Hsu SC, Kee Y, Hopf FW, Scheller RH. 1999. The sec6/8 complex is located at neurite outgrowth and axonal synapse-assembly domains. J Neurosci 19: $1324-1334$.

He B, Guo W. 2009. The Exocyst Complex in Polarized Exocytosis. Curr Opin Cell Biol doi: 10.1016/ j.ceb.2009.04.007.

He B, Xi F, Zhang J, TerBush D, Zhang X, Guo W. 2007a. Exo70p mediates the secretion of specific exocytic vesicles at early stages of the cell cycle for polarized cell growth. $J$ Cell Biol 176: 771-777.

He B, Xi F, Zhang X, Zhang J, Guo W. 2007b. Exo70 interacts with phospholipids and mediates the targeting of the exocyst to the plasma membrane. EMBO $J$ 26: 4053-4065.

Hsu SC, TerBush D, Abraham M, Guo W. 2004. The exocyst complex in polarized exocytosis. Int Rev Cytol 233: 243-265.

Hsu SC, Ting AE, Hazuka CD, Davanger S, Kenny JW, Kee Y, Scheller RH. 1996. The mammalian brain rsec6/8 complex. Neuron 17: 1209-1219.

Huang YE, Iijima M, Parent CA, Funamoto S, Firtel RA, Devreotes P. 2003. Receptor-mediated regulation of 
PI3Ks confines PI $(3,4,5) \mathrm{P} 3$ to the leading edge of chemotaxing cells. Mol Biol Cell 14: 1913-1922.

Hutagalung AH, Coleman J, Pypaert M, Novick PJ. 2009. An internal domain of EXO70P is required for actin-independent localization and mediates assembly of specific exocyst components. Mol Biol Cell 20: $153-163$.

Iijima M, Huang YE, Devreotes P. 2002. Tumor suppressor PTEN mediates sensing of chemoattractant gradients. Dev Cell 3: 469-478.

Inoue M, Chang L, Hwang J, Chiang SH, Saltiel AR. 2003. The exocyst complex is required for targeting of Glut 4 to the plasma membrane by insulin. Nature 422: 629-633.

Irazoqui JE, Gladfelter AS, Lew DJ. 2003. Scaffold-mediated symmetry breaking by Cdc42p. Nat Cell Biol 5: 1062-1070.

Irazoqui JE, Howell AS, Theesfeld CL, Lew DJ. 2005. Opposing roles for actin in Cdc42p polarization. $\mathrm{Mol}$ Biol Cell 16: 1296-1304.

Jedd G, Mulholland J, Segev N. 1997. Two new Ypt GTPases are required for exit from the yeast trans-Golgi compartment. J Cell Biol 137: 563-580.

Jiang H, Guo W, Liang X, Rao Y. 2005. Both the establishment and the maintenance of neuronal polarity require active mechanisms: Critical roles of GSK- $3 \beta$ and its upstream regulators. Cell 120: 123-135.

Kawase K, Nakamura T, Takaya A, Aoki K, Namikawa K, Kiyama H, Inagaki S, Takemoto H, Saltiel AR, Matsuda M. 2006. GTP hydrolysis by the Rho family GTPase TC10 promotes exocytic vesicle fusion. Dev Cell 11: 411-421.

Kee Y, Yoo JS, Hazuka CD, Peterson KE, Hsu SC, Scheller RH. 1997. Subunit structure of the mammalian exocyst complex. Proc Natl Acad Sci 94: 14438-14443.

Kozminski KG, Alfaro G, Dighe S, Beh CT. 2006. Homologues of oxysterol-binding proteins affect Cdc42p- and Rholp-mediated cell polarization in Saccharomyces cerevisiae. Traffic 7: 1224-1242.

Kozubowski L, Saito K, Johnson JM, Howell AS, Zyla TR, Lew DJ. 2008. Symmetry-breaking polarization driven by a Cdc42p GEF-PAK complex. Curr Biol 18: 1719-1726.

Kroschewski R, Hall A, Mellman I. 1999. Cdc42 controls secretory and endocytic transport to the basolateral plasma membrane of MDCK cells. Nature Cell Biol 1: $8-13$.

Langevin J, Morgan MJ, Sibarita JB, Aresta S, Murthy M, Schwarz T, Camonis J, Bellaïche Y. 2005. Drosophila exocyst components Sec5, Sec6, and Sec15 regulate DE-Cadherin trafficking from recycling endosomes to the plasma membrane. Dev Cell 9: 365-376.

Larue L, Ohsugi M, Hirchenhain J, Kemler R. 1994 E-cadherin null mutant embryos fail to form a trophectoderm epithelium. PNAS 91: 8263-8267.

Le TL, Yap AS, Stow JL. 1999. Recycling of E-cadherin: A potential mechanism for regulating cadherin dynamics. J Cell Biol 146: 219-232.

Leevers SJ, Vanhaesebroeck B, Waterfield MD. 1999. Signalling through phosphoinositide 3-kinases: The lipids take centre stage. Curr Opin Cell Biol 11: 219-225.
Lehman K, Rossi G, Adamo JE, Brennwald P. 1999. Yeast homologues of tomosyn and lethal giant larvae function in exocytosis and are associated with the plasma membrane SNARE, Sec9. J Cell Biol 146: 125-140.

Li R, Bowerman B. 2009. Symmetry breaking in biology. Cold Spring Harb Perspect Biol 2: a003475.

Li BX, Satoh AK, Ready DF. 2007. Myosin V, Rab11, and dRip11 direct apical secretion and cellular morphogenesis in developing Drosophila photoreceptors. J Cell Biol 177: 659-669.

Li J, Ballif BA, Powelka AM, Dai J, Gygi SP, Hsu VW. 2005. Phosphorylation of ACAP1 by Akt regulates the stimulation-dependent recycling of integrin $\beta 1$ to control cell migration. Dev Cell 9: 663-673.

Li Z, Hannigan M, Mo Z, Liu B, Lu W, Wu Y, Smrcka AV, Wu G, Li L, Liu M, et al. 2003. Directional sensing requires G $\beta \gamma$-mediated PAK1 and PIX $\alpha$-dependent activation of Cdc42. Cell 114: 215-227.

Lipatova Z, Tokarev AA, Jin Y, Mulholland J, Weisman LS, Segev N. 2008. Direct interaction between a myosin V motor and the Rab GTPases Ypt31/32 is required for polarized secretion. Mol Biol Cell 19: 4177-4187.

Lipschutz JH, Mostov KE. 2002. Exocytosis: The many masters of the exocyst. Curr Biol 12: R212-R214.

Liu J, Zuo X, Yue P, Guo W. 2007. Phosphatidylinositol 4, 5bisphosphate mediates the targeting of the exocyst to the plasma membrane for exocytosis in mammalian cells Mol Biol Cell 18: 4483-4492.

Lu H, Bilder D. 2005. Endocytic control of epithelial polarity and proliferation in Drosophila. Nat Cell Biol 7: $1232-1239$.

Marco E, Wedlich-Soldner R, Li R, Altschuler SJ, Wu LF. 2007. Endocytosis optimizes the dynamic localization of membrane proteins that regulate cortical polarity. Cell 129: 411-422.

Martin-Belmonte F, Gassama A, Datta A, Yu W, Rescher U, Gerke V, Mostov K. 2007. PTEN-mediated apical segregation of phosphoinositides controls epithelial morphogenesis through Cdc42. Cell 128: 383-397.

Matern HT, Yeaman C, Nelson WJ, Scheller RH. 2001. The Sec6/8 complex in mammalian cells: Characterization of mammalian Sec3, subunit interactions, and expression of subunits in polarized cells. Proc Natl Acad Sci 98: 9648-9653.

McCaffrey LM, Macara IG. 2009. Widely conserved signaling pathways in the establishment of cell polarity. Cold Spring Harb Perspect Biol 1: a001370.

Mellman I, Nelson WJ. 2008. Coordinated protein sorting, targeting and distribution in polarized cells. Nat Rev Mol Cell Biol 9: 833-845.

Miranda KC, Joseph SR, Yap AS, Teasdale RD, Stow JL. 2003. Contextual binding of p120ctn to E-cadherin at the basolateral plasma membrane in polarized epithelia. J Biol Chem 278: 43480-43488.

Miranda KC, Khromykh T, Christy P, Le TL, Gottardi CJ, Yap AS, Stow JL, Teasdale RD. 2001. A dileucine motif targets E-cadherin to the basolateral cell surface in Madin-Darby canine kidney and LLC-PK1 epithelial cells. J Biol Chem 276: $22565-22572$.

Mullins D. 2009. Symmetry breaking in biology. Cold Spring Harb Perspect Biol 2: a003392. 
K. Orlando and W. Guo

Murthy M, Garza D, Scheller RH, Schwarz TL. 2003. Mutations in the exocyst component Sec5 disrupt neuronal membrane traffic, but neurotransmitter release persists. Neuron 37: 433-447.

Müsch A, Cohen D, Kreitzer G, Rodriguez-Boulan E. 2001 $\mathrm{Cdc} 42$ regulates the exit of apical and basolateral proteins from the trans-Golgi network. EMBO J. 20: 2171-2179.

Nachury MV, Loktev AV, Zhang Q, Westlake CJ, Peränen J, Merdes A, Slusarski DC, Scheller RH, Bazan JF, Sheffield VC, et al. 2007. A core complex of BBS proteins cooperates with the GTPase Rab8 to promote ciliary membrane biogenesis. Cell 129: 1201-1213.

Nejsum LN, Nelson WJ. 2007. A molecular mechanism directly linking E-cadherin adhesion to initiation of epithelial cell surface polarity. J Cell Biol 178: 323-335.

Nelson WJ. 2009. Remodeling epithelial cell organization Transitions between front-rear and apical-basal polarity. Cold Spring Harb Perspect Biol 1: a000513.

Novick P, Guo W. 2002. Ras family therapy: Rab, Rho and Ral talk to the exocyst. Trends Cell Biol 12: 247-249.

Novick P, Field C, Schekman R. 1980. Identification of 23 Complementation Groups Required for Posttranslational Events in the Yeast Secretory Pathway. Cell 21: 205-215.

Orlando K, Zhang J, Zhang X, Yue P, Chiang T, Bi E, Guo W 2008. Regulation of Gic2 localization and function by phosphatidylinositol 4,5-bisphosphate during the establishment of cell polarity in budding yeast. J Biol Chem 283: 14205-14212.

Ortiz D, Medkova M, Walch-Solimena C, Novick P. 2002. Ypt32 recruits the Sec4p guanine nucleotide exchange factor, Sec2p, to secretory vesicles; evidence for a Rab cascade in yeast. J Cell Biol 157: 1005-1015.

Oztan A, Silvis M, Weisz OA, Bradbury NA, Hsu SC, Goldenring JR, Yeaman C, Apodaca G. 2007. Exocyst requirement for endocytic traffic directed toward the apical and basolateral poles of polarized MDCK cells. Mol Biol Cell 18: 3978-3992.

Park HO, Bi E. 2007. Central roles of small GTPases in the development of cell polarity in yeast and beyond. Microbiol Mol Biol Rev 71: 48-96.

Pfeffer SR. 1999. Transport-vesicle targeting: Tethers before SNAREs. Nat Cell Biol 1: E17-E22.

Pinal N, Goberdhan DC, Collinson L, Fujita Y, Cox IM, Wilson C, Pichaud F. 2006. Regulated and polarized PtdIns(3,4,5)P3 accumulation is essential for apical membrane morphogenesis in photoreceptor epithelial cells. Curr Biol 16: 140-149.

Powelka AM, Sun J, Li J, Gao M, Shaw LM, Sonnenberg A, Hsu VW. 2004. Stimulation-dependent recycling of integrin $\beta 1$ regulated by ARF6 and Rab11. Traffic 5: 20-36.

Prehoda KE, Scott JA, Mullins RD, Lim WA. 2000 Integration of multiple signals through cooperative regulation of the N-WASP-Arp2/3 complex. Science 290: $801-806$.

Prehoda KE. 2009. Polarization of Drosophila neuroblasts during asymmetric division. Cold Spring Harb Perspect Biol 1: a001388.

Price MS, Nichols CB, Alspaugh JA. 2008. The Cryptococcus neoformans Rho-GDP dissociation inhibitor mediates intracellular survival and virulence. Infect Immun 76: 5729-5737.

Prigozhina NL, Waterman-Storer CM. 2004. Protein kinase D-mediated anterograde membrane trafficking is required for fibroblast motility. Curr Biol 14: 88-98.

Proux-Gillardeaux V, Gavard J, Irinopoulou T, Mège RM, Galli T. 2005. Tetanus neurotoxin-mediated cleavage of cellubrevin impairs epithelial cell migration and integrin-dependent cell adhesion. PNAS 102: 6362-6367.

Pruyne D, Legesse-Miller A, Gao L, Dong Y, Bretscher A. 2004a. Mechanisms of polarized growth and organelle segregation in yeast. Annu Rev Cell Dev Biol 20: 559-591.

Pruyne D, Gao L, Bi Bretscher A. 2004b. Stable and dynamic axes of polarity use distinct formin isoforms in budding yeast. Mol Biol Cell 15: 4971-4989.

Roberg KJ, Rowley N, Kaiser CA. 1997. Physiological regulation of membrane protein sorting late in the secretory pathway of Saccharomyces cerevisiae. J Cell Biol 137: 1469-1482.

Roberts M, Barry S, Woods A, van der Sluijs P, Norman J. 2001. PDGF-regulated rab4-dependent recycling of $\alpha v \beta 3$ integrin from early endosomes is necessary for cell adhesion and spreading. Curr Biol 11: 1392-1402.

Robinson NG, Guo L, Imai J, Toh-E A, Matsui Y, Tamanoi F. 1999. Rho3 of Saccharomyces cerevisiae, which regulates the actin cytoskeleton and exocytosis, is a GTPase which interacts with Myo2 and Exo70. Mol Cell Biol 19: 3580-3587.

Rodriguez-Boulan E, Müsch A. 2005. Protein sorting in the Golgi complex: Shifting paradigms. Biochim Biophys Acta 1744: 455-464.

Rohatgi R, Ho HY, Kirschner MW. 2000. Mechanism of N-WASP activation by CDC42 and phosphatidylinositol 4, 5-bisphosphate. J Cell Biol 150: 1299-1310.

Rosse C, Hatzoglou A, Parrini MC, White MA, Chavrier P, Camonis J. 2006. RalB mobilizes the exocyst to drive cell migration. Mol Cell Biol 26: 727-734.

Salminen A, Novick PJ. 1987. A ras-like protein is required for a post-Golgi event in yeast secretion. Cell 49: 527-538.

Servant G, Weiner OD, Herzmark P, Balla T, Sedat JW, Bourne HR. 2000. Polarization of chemoattractant receptor signaling during neutrophil chemotaxis. Science 287: 1037-1040.

Shen L, Weber CR, Turner JR. 2008. The tight junction protein complex undergoes rapid and continuous molecular remodeling at steady state. J Cell Biol 181: 683-695.

Shi SH, Jan LY, Jan YN. 2003. Hippocampal neuronal polarity specified by spatially localized mPar3/mPar6 and PI 3-kinase activity. Cell 112: 63-75.

Singer SJ, Kupfer A. 1986. The directed migration of eukaryotic cells. Annu Rev Cell Biol 2: 337-365.

Slaughter BD, Smith SE, Li R. 2009. Symmetry breaking in the life cycle of the budding yeast. Cold Spring Harb Perspect Biol 1: a003384.

Swiatecka-Urban A, Talebian L, Kanno E, Moreau-Marquis S, Coutermarsh B, Hansen K, Karlson KH, Barnaby R, Cheney RE, Langford GM, et al. 2007. Myosin Vb is required for trafficking of the cystic fibrosis transmembrane conductance regulator in Rablla-specific apical 
recycling endosomes in polarized human airway epithelial cells. J Biol Chem 282: 23725-23736.

Tayeb MA, Skalski M, Cha MC, Kean MJ, Scaife M, Coppolino MG. 2005. Inhibition of SNARE-mediated membrane traffic impairs cell migration. Exp Cell Res 305: 63-73.

Tcheperegine SE, Gao XD, Bi E. 2005. Regulation of cell polarity by interactions of Msb3 and Msb4 with Cdc42 and polarisome components. Mol Cell Biol 25: 8567-8580.

Terai T, Nishimura N, Kanda I, Yasui N, Sasaki T. 2008. JRAB/MICAL-L2 is a junctional Rab13-binding protein mediating the endocytic recycling of occludin. Mol Biol Cell 17: 2465-2475.

TerBush D, Novick P. 1995. Sec6, Sec8, and Secl5 are components of a multisubunit complex which localizes to small bud tips in Saccharomyces cerevisiae. J Cell Biol 130: 299-312.

TerBush D, Maurice T, Roth D, Novick P. 1996. The Exocyst is a multiprotein complex required for exocytosis in Saccharomyces cerevisiae. EMBO J 15: 6483-6494.

Tiedje C, Sakwa I, Just U, Höfken T. 2008. The Rho GDI Rdil regulates Rho GTPases by distinct mechanisms. Mol Biol Cell 19: 2885-2896.

Ting AE, Hazuka CD, Hsu SC, Kirk MD, Bean AJ, Scheller RH. 1995, rSec6 and rSec8, mammalian homologs of yeast proteins essential for secretion. Proc Natl Acad Sci 92: 9613-9617.

Tolliday N, VerPlank L, Li R. 2002. Rho1 Directs ForminMediated Actin Ring Assembly during Budding Yeast Cytokinesis. Curr Biol 12: $1864-1870$.

Uemura T, Oda H, Kraut R, Hayashi S, Kataoka Y, Takeichi M. 1996. Zygotic Drosophilia E-cadherin expression is required for processes of dynamic epithelial cell rearrangement in the Drosophila embryo. Genes Dev 10: 659-671.

Vega IE, Hsu SC. 2001. The exocyst complex associates with microtubules to mediate vesicle targeting and neurite outgrowth. J Neurosci 21: 3839-3848.

Wang Z, Edwards JG, Riley N, Provance DWJr, Karcher R, Li XD, Davison IG, Ikebe M, Mercer JA, Kauer JA, Ehlers MD. 2008. Myosin Vb mobilizes recycling endosomes and AMPA receptors for postsynaptic plasticity. Cell 135: $535-548$.

Wedlich-Soldner R, Altschuler S, Wu L, Li R. 2003. Spontaneous cell polarization through actomyosin-based delivery of the Cdc42 GTPase. Science 299: 1231-1235.

Willard SS, Devreotes PN. 2006. Signaling pathways mediating chemotaxis in the social amoeba, Dictyostelium discoideum. Eur J Cell Biol 85: 897-904.
Wu S, Mehta SQ, Pichaud F, Bellen HJ, Quiocho FA. 2005. Sec15 interacts with Rab11 via a novel domain and affects Rab11 localization in vivo. Nat Struct Mol Biol 12: $879-885$.

Yadav S, Puri S, Linstedt AD. 2009. A primary role for Golgi positioning in directed secretion, cell polarity, and wound healing. Mol Biol Cell. 20: 1728-1736.

Yamada S, Pokutta S, Drees F, Weis WI, Nelson WJ. 2005. Deconstructing the cadherin-catenin-actin complex. Cell 123: 889-901.

Yap AS, Crampton MS, Hardin J. 2007. Making and breaking contacts: The cellular biology of cadherin regulation. Curr Opin Cell Biol 19: 508-514.

Yeaman C, Grindstaff KK, Nelson WJ. 2004. Mechanism of recruiting Sec6/8 (exocyst) complex to the apical junctional complex during polarization of epithelial cells. J Cell Sci 117: 559-570.

Yeaman C, Grindstaff KK, Wright JR, Nelson WJ. 2001. Sec6/8 complexes on trans-Golgi network and plasma membrane regulate late stages of exocytosis in mammalian cells. J Cell Biol 155: 593-604.

Yoshimura S, Egerer J, Fuchs E, Haas AK, Barr FA. 2007. Functional dissection of Rab GTPases involved in primary cilium formation. J Cell Biol 178: 363-369.

Zajac A, Sun X, Zhang J, Guo W. 2005. Cyclical regulation of the exocyst and cell polarity determinants for polarized cell growth. Mol Biol Cell 16: 1500-1512.

Zerial M, McBride H. 2001. Rab proteins as membrane organizers. Nat Rev Mol Cell Biol 2: 107-117.

Zhang X, Bi E, Novick P, Du L, Kozminski KG, Lipschutz JH, Guo W. 2001. Cdc42 interacts with the exocyst and regulates polarized secretion. J Biol Chem 276: 46745-46750.

Zhang XM, Ellis S, Sriratana A, Mitchell CA, Rowe T. 2004. Sec15 is an effector for the Rab11 GTPase in mammalian cells. J Biol Chem 279: 43027-43034.

Zhang X, Orlando K, He B, Xi F, Zhang J, Zajac A, Guo W. 2008. Membrane association and functional regulation of Sec3 by phospholipids and Cdc42. J Cell Biol 180: $145-158$.

Zhang X, Wang P, Gangar A, Zhang J, Brennwald P, TerBush D, Guo W. 2005b. Lethal giant larvae proteins interact with the exocyst complex and are involved in polarized exocytosis. J Cell Biol 170: 273-283.

Zhang X, Zajac A, Zhang J, Li M, Murray J, TerBush D, Guo W. 2005a. The critical role of Exo84p in the organization and polarized localization of the exocyst complex. J Biol Chem 280: 20356-20364.

Zuo X, Zhang J, Zhang Y, Hsu SC, Zhou D, Guo W. 2006. Exo70 interacts with the Arp2/3 complex and regulates cell migration. Nat Cell Biol 8: 1383-1388. 


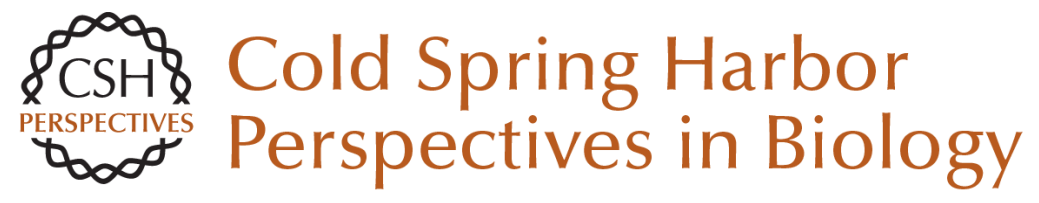

\section{Membrane Organization and Dynamics in Cell Polarity}

Kelly Orlando and Wei Guo

Cold Spring Harb Perspect Biol 2009; doi: 10.1101/cshperspect.a001321 originally published online August 19, 2009

Subject Collection Symmetry Breaking in Biology

Cytoskeletal Mechanisms for Breaking Cellular Symmetry

R. Dyche Mullins

Symmetry Breaking in Biology

Rong Li and Bruce Bowerman

Planar Cell Polarity Signaling: The Developing

Cell's Compass

Eszter K. Vladar, Dragana Antic and Jeffrey D. Axelrod

Cellular Polarity in Prokaryotic Organisms Jonathan Dworkin

Symmetry Breaking in Plants: Molecular Mechanisms Regulating Asymmetric Cell

Divisions in Arabidopsis Jalean J. Petricka, Jaimie M. Van Norman and Philip N. Benfey

The Signaling Mechanisms Underlying Cell

Polarity and Chemotaxis Fei Wang

Polarization of Drosophila Neuroblasts During Asymmetric Division Kenneth E. Prehoda

Physical Model of Cellular Symmetry Breaking Jasper van der Gucht and Cécile Sykes
Polarity in Stem Cell Division: Asymmetric Stem

Cell Division in Tissue Homeostasis

Yukiko M. Yamashita, Hebao Yuan, Jun Cheng, et al.

Symmetry Breaking in the Life Cycle of the

Budding Yeast

Brian D. Slaughter, Sarah E. Smith and Rong Li

Neuronal Polarity

Sabina Tahirovic and Frank Bradke

Membrane Organization and Dynamics in Cell

Polarity Kelly Orlando and Wei Guo

Cellular Symmetry Breaking during

Caenorhabditis elegans Development Edwin Munro and Bruce Bowerman

Symmetry Breaking During Drosophila Oogenesis Siegfried Roth and Jeremy A. Lynch

Widely Conserved Signaling Pathways in the Establishment of Cell Polarity Luke Martin McCaffrey and lan G. Macara

Shaping Fission Yeast with Microtubules Fred Chang and Sophie G. Martin

For additional articles in this collection, see http://cshperspectives.cshlp.org/cgi/collection/

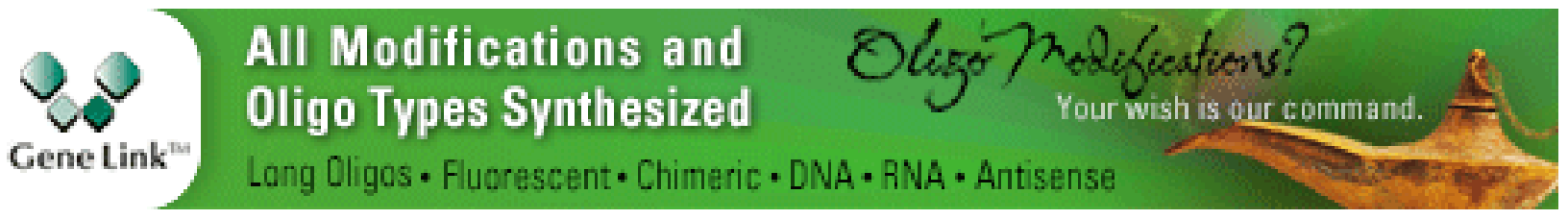

